\title{
11. MODERN TEACHING METHODS IN CREATIVE WORKSHOP FASHION DESIGN COURSES
}

\author{
Ondina-Oana Turturică ${ }^{93}$
}

\begin{abstract}
The aim of this article is to specify and exemplify the stages of the creative process in fashion design courses and workshops, with a focus on a few learning methods exploring the creative potential through content and visual analysis processes as well as more practical techniques and methods in the area of fashion design and applied arts. From scientific documentation to pedagogical experiments, a range of methods have been used to enable students fulfill their learning objectives and reach the apex of professional competence.
\end{abstract}

Key words: method, teaching, design, visual, creativity

\section{Introduction}

The Bologna Process triggered a reformation in the higher education system and with it, a greater mobility for both professors and students. The content of this article is focused on presenting some of the contemporary teaching methods applied in the creative workshop fashion design courses. The specifications and examples are based on the practical activities carried out in the fashion design department. However, they remain valid for all the creative industries where fashion design professionals need to be formed, including activities and methods that take into consideration the current higher education changes, whereby a "functional reactivation between the educational supply and employers' demand" is mandatory.

Bearing this in mind, our academic mission would be to consolidate the knowledge accumulated and forge competencies so that the new generation stands out through socially active creative designers. The creative process within the fashion design workshops comprises the documentation on a given theme or subject, through images and texts, research on various alternatives, options and standpoints of other authors (artists). All these enable students to generate new ideas and content on the given subject.

The ideas generated throughout the creative process via the reformulation of new concepts, hypotheses and creative solutions, are ultimately evaluated in order to assess their functionality and validity in the context under discussion. Therefore, the students can make use, during the workshops or self-study hours, of the creative skills which uniquely benefit their understanding and can apply creative techniques and elements, assimilating in this context the psychoergonomic factors, based on the learning methods used through processes such as imagination and attention.

\footnotetext{
93 Assistant PhD., ”Aurel Vlaicu” University from Arad, Romania, email: ondyna_oana@yahoo.com
} 


\section{Discussions}

Thus, structure and metaphor are dissociated and immersed in themes, through new creative forms, into projects based on the visual and applied arts through a continuous attempt to reorganize the knowledge gained, combine and recombine, with the final purpose of accomplishing the goals set and gaining new working skills, transposition methods and techniques through imaginative and innovative mechanisms. Such creative mechanisms mostly depend on selective orientation and concentration on the psychological processes, for an understanding of the work techniques and of the visual content input provided by the teacher. The process of managing attention as effectively as possible relies to a great extent on the teacher's but also on the student's capacity to concentrate, to become flexible and a multi-tasker. Against this backdrop, one can see that the cognitive and affective processes are also necessary aside from attention, motivation and personal talent, in an attempt to make use as much as possible of both the psychological and biological functions, for the determination of an optimal result in the accumulation of practical and informative skills.

Therefore, in the approach and teaching methods used, the teacher has to take into account students' personality, i.e. their thought process, memory, imagination, attention and ways of rendering perception. Creative thinking stems out of the stimulation of new ideas through knowledge, analysis and reinterpretation of other ideas but also through collaboration, to obtain cultural and social diversity. Therefore, the teaching methods need to be adapted from group to group, as diversely as possible, bearing in mind the students' creative potential, their adaptation and perception level, during the teaching sessions. The capacity of being creative resides in original ideas, which gain value when developed in a given context, taking into consideration various external factors that influence the fashion object's projection both aesthetically and functionally. This is possible by applying new transposition techniques via software applications and digital technologies used in the development and projection of a new fashion concept, which includes a variety of visual aspects through the new digital technologies.

Just as Sir Ken Robinson (2009, pp. 22-26) stated, "creativity is a process which requires certain skills, science, control, inspiration and imagination". It involves affective, cognitive and pragmatic processes that demand adaptation to the theme of a certain language, for skill and interest diversification as well as student motivation. Receiving and understanding the input content by the student through active participation in line with the delineated objectives takes place most of the times through the production of clothing items that get to be promoted through new communication ways or, in the case of the "objectdesign" concept - the clothing ensemble becomes a ready-made object introduced in the artistic circuit. Thus, fashion adopts as expression, forms and artistic experiment activities which catapult it into the artistic circuit, reimaging it as a work of art through a well-defined artistic language. The result of such combinations is a form modification, according to the model of "installation" in 
art, whereby clothing items are recontextualized in the terms of contemporary society and its necessities.

Therefore, the learning process during the workshops is based on contemporary educational principles, drawing on praxeological concepts, through an active participation and learning or through the "componential construction" construct, whereby content structure is grouped on sections that can trigger individual learning efficiency. The input received from the teacher is not fragmented but unified into an informational whole, having in mind the level of students' in each group. In the present article, we will continue with the presentation of two teaching methods successfully used in our creative workshops. These are the MIAC method (learning through content analysis) and the MHM method (mental chart method). Both are used to prevent the exploitation of the symbolic and constructive potential in order to encourage student creativity.

The MHM method is successfully applied as a functional unity of the mental image, making use of recognizable signs and symbols - in our case through an imagistic variety where emphasis is put on the particularization of the clothing items' functionality, according to the theme discussed. Thus, students' are free to create a costume in line with their own plastic fantasy through a formal compositional model, which allows reconstruction through revocation in an innovative manner, for the production of new mental associations. These mental representations, which are used from documentation phase of the study theme, transmit (according to M. Joly in his paper published in 1998), "the thinking essence through a condensed message", which ultimately helps the student to complete the pretext sketches, giving the costume (clothing or decorative piece) a meta signification which goes beyond its symbolic function reaching the concept of "status symbolus" of the clothing item analyzed from both a sculptural as well as a visual and semantic perspective.

Through the initial contextual associations, the student will have the impression of "composition", i.e. of a predictable mental structure, set to help in fulfilling the image analogies wherein form authenticity is condensed as well as the symbolic content of the analyzed visual image in the given context at that moment. Therefore, images and symbols are unified forming "frames" founded on the sign-symbol binomial relationship, through a semiotic with a coded plastic language and communicational meaning, in which texture, colour and painting develop certain associations with aesthetic values, which represent well-defined ideas whereby the teacher adopts a cognitive mediation role towards the student, offering technical alternatives for the transposition of the sketched object.

The qualitative MIAC method offers learning alternatives through the productive research of images or texts, through the plastic language decoding of the latter, through the evaluation and interpretation of the elements and aspects under discussion - in this case, expressed through different styles, seen as selfidentity brands, which place the clothing item in its own symbolic system, 
operating at a social level through its own system, which needs to be interpreted according to its specific forms.

\section{Conclusions}

This individual study method entails, as a predominant orientation, the contextual study of artistic work interpretation from a significance standpoint. In order to improve the modernized curriculum for skill formation in students, the dominant orientation will be based on contextual, interpretative study of the works for which the analysis criteria are based on their values, concept significance and message interlinkage. In the student skill formation context, the individual capabilities mainly targeted are the completion of form-content, intention-manner unity, message correlation with author intention, improvement of the enrichment capacity of various practical concepts of innovation through creative teaching strategies - learning to surpass intuitive uncertainty and forming the capacity of correct message interpretation as well as symbol and visual discourse.

\section{Bibliography}

1. Grize, J.B. (1971). Logique de l'argumentation et discours argumentatif. Travaux du CDRS, nr. 7. Suisse: Universite de Neuchâtel.

2. Ionescu, M. \& Radu, I. (1995). Didactica modernă. Cluj-Napoca: Dacia.

3. Mara, D. (2010). Stiluri de învățare la studenți. Cluj-Napoca: Universitatea Babeș-Bolyai, Facultatea de Psihologie și Științe ale Educației.

4. Neacșu, I. (2006). Invățarea academică independentă. Ghid Metodologic. București: Facultatea de Psihologie și Știinţele Educației.

5. Robinson, K. (2009). Teaching for the 21 st Century. 67(1), 22-26. 